\title{
SAPALDIA 2: the cohort continues
}

Dr. Samet is professor of epidemiology and chairman of the Department of Epidemiology at the Johns Hopkins Bloomberg School of Public Health, Baltimore, USA

\section{Published Online First: 21 July 2005}

In spite of declining levels of air pollution in countries of Europe and North America over recent decades, epidemiological studies continue to show that current levels of air pollution are adversely affecting public health. The most widely measured indicators, particulate matter and ozone, have been associated with premature mortality and with diverse morbidity indicators at concentrations routinely measured in urban environments. The evidence on mortality, coming from many daily time-series studies and a small number of cohort studies, has been particularly powerful in motivating more stringent regulations for particulate matter. The findings of the time-series studies and cohort studies are complementary, as the increased risk observed over the longer-term in the cohort studies implies that air pollution is leading to sufficient life-shortening to be of public health concern.

Only a small number of cohort studies have been carried out specifically to characterize the health effects of air pollution. Some of the landmark investigations include the pioneering study of Berlin, New Hampshire residents started by Benjamin Ferris in the 1960s (Ferris \& Anderson 1963), the Six Cities Study started by Ferris in 1974 along with a team that also included Frank Speizer, James Ware, and John Spengler (Ferris et al. 1979), and most recently the Children's Health Study in Southern California (Peters et al. 1999). Cohort studies implemented for other purposes have also been opportunistically used to test hypotheses related to air pollution. For example, Pope and colleagues (Pope et al. 1995; 2002) turned to the American Cancer Society's Cancer Prevention Study (CPS) II study to confirm the positive association of mortality with particulate matter that was found with follow-up of the adults in the Six Cities Study (Dockery et al. 1993). CPS II, a cohort study of over one million Americans, was initially established to assess causes of cancer. More recently, the US Environmental Protection Agency has funded a 10-year study of air pollution and cardiovascular disease that draws on the framework offered by an ongoing multicenter study of early cardiovascular disease, the MultiEthnic Study of Atherosclerosis (MESA) (Bild et al. 2002). In this issue of Social and Preventive Medicine, AckermannLiebrich and colleagues (2005) describe the first follow-up of the Swiss Cohort Study on Air Pollution and Lung Diseases in Adults (SAPALDIA). The paper describes a rich suite of measurements, questionnaires, and biological sample collection, as well as remarkably high rate of retention over the dozen years since the participants were enrolled. The study design incorporates detailed physiological assessment with nesting of specific elements, such as Holter monitoring, for efficiency, a "biobank", and an air pollution exposure assessment strategy based in use of GIS methods. This follow-up phase of SAPALDIA (SAPALDIA 2) will undoubtedly provide a rich data resource for testing hypotheses related not only to air pollution but to other factors that affect respiratory and cardiovascular health.

Over the next few years, we should watch for a new series of papers from the SAPALDIA team. Findings should be anticipated on air pollution exposure over the years of follow-up and changes in respiratory symptoms and lung function from baseline. The study will also provide insights into air pollution exposure and methacholine responsiveness and heart rhythm effects. The investigators will face the inevitable challenges arising with any cohort study of air pollution: sample size and precision of estimates, exposure misclassification, and generalizability of findings. Looking forward, they have established the biobank and will be able to test hypotheses related to genetic determinants of responses to air pollution, as well as to test more general genetic associations. Assessments of gene-environment interaction for air pollution are likely to be frustrated by inadequate power, given the sample size needs for such assess- 
ments (Garcia-Closas et al. 1999; Garcia-Closas \& Lubin 1999). The declining air pollution concentrations in the SAPALDIA cities have also decreased the exposure gradient across the eight cities; the increasingly homogeneous exposures of the study participants may further limit power. Nonetheless, I anticipate that much will be learned from SAPALDIA 2.

SAPALDIA represents one approach to longitudinal investigation of the health effects of air pollution. Like the Six Cities Study, SAPALDIA was implemented specifically to address the health effects of air pollution; a substantial level of funding is needed over the long-term to conduct such studies, particularly if they are of sufficient size and incorporate a range of outcome measures and state-of-art exposure assessment. Alternative, but complementary approaches are needed that might be based in cohort studies established for other purposes or in cohorts that can be defined through administrative data bases. For example, we have defined a cohort of participants in the Medicare system in the United States, which provides health care coverage for nearly all persons over age 65 years. We link address location to concentrations of $P M_{2.5}$ (particulate matter less than 2.5 microns in aerodynamic diameter) to estimate exposures. The resulting cohort numbers about 20 million and the data base provides information on hospitalizations and mortality. However, with the Medicare data, we lack the rich detail on potential confounders and modifiers that is available in SAPALDIA.

I look forward to the findings of SAPALDIA 2 and, of course, to those of the next round, SAPALDIA 3.

Jonathan M. Samet

\begin{abstract}
References
Ackermann-Liebrich U, Kuna-Dibbert B, ProbstHensch NM, et al. (2005). Follow-up of the Swiss Cohort Study on Air Pollution and Lung Diseases in Adults (SAPALDIA 2) 1991-2003: methods and characterization of participants. Soz Praventiv Med 50: 245-263.
\end{abstract}

Bild DE, Bluemke DA, Burke GL, et al. (2002). Multi-ethnic study of atherosclerosis: objectives and design. Am J Epidemiol 156: 871-81.

Dockery DW, Pope CA, III, Xu X, et al. (1993). An association between air pollution and mortality in six U.S. cities. N Engl J Med 329: 1753-9.

Ferris BG, Jr., Anderson DO (1963). The prevalence of chronic respiratory disease in a New Hampshire town. Am Rev Respir Dis 86: 165-77.
Ferris BG, Jr., Speizer FE, Spengler JD, et al. (1979). Effects of sulfur oxides and respirable particles on human health: methodology and demography of populations in study. Am Rev Respir Dis 120: 767-79.

Garcia-Closas M, Lubin JH (1999). Power and sample size calculations in case-control studies of gene-environment interactions: comments on different approaches. Am J Epidemiol 149: 689-92.

Garcia-Closas M, Rothman N, Lubin J (1999). Misclassification in case-control studies of geneenvironment interactions: assessment of bias and sample size. Cancer Epidemiol Biomarkers Prev 8: 1043-50.

Peters JM, Avol E, Navidi W, et al. (1999). A study of twelve Southern California communities with differing levels and types of air pollution. I. Prevalence of respiratory morbidity. Am J Resp Crit Care Med 159: 760-7.
Pope CA, III, Burnett RT, Thun MJ, et al. (2002). Lung cancer, cardiopulmonary mortality, and long-term exposure to fine particulate air pollution. JAMA 287: 1132-41.

Pope CA, III, Thun MJ, Namboodiri MM, et al. (1995). Particulate air pollution as a predictor of mortality in a prospective study of U.S. adults. Am J Resp Crit Care Med 151: 669-74.

Address for correspondence

Jonathan M. Samet, MD, MS Professor and Chairman Department of Epidemiology Johns Hopkins Bloomberg School of Public Health 615 N. Wolfe Street, Rm. W6041 Baltimore, MD 21205 USA e-mail: jsamet@jhsph.edu 